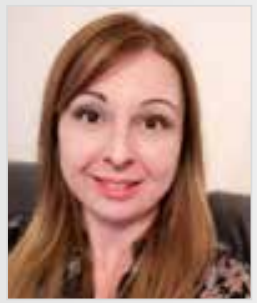

Szerzo" / rovatvezetô: MATÓ-JUHÁSZ ANNAMÁRIA

Miskolci Egyetem Gazdasáqtudományi Kar Whole life balance specialista efkegtur@uni-miskolc.hu egyetemi tanársegéd, Ph.D hallgató kutatási terület: Az egészségtudatos magatartás fejlesztése a társadalmi marketing eszközeivel juhasz.ancsa@uni-miskolc.hu

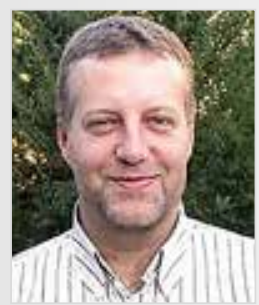

Szerző: DR. DÓZSA CSABA

Egyetemi docens,

Miskolci Egyetem Egészségügyi Kar

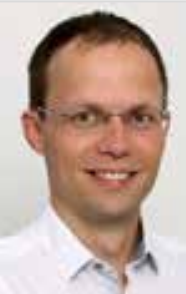

Szerző: DR. BABAI LÁSZLÓ

Életmód orvos, Prima Medica

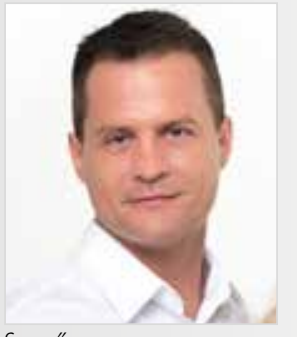

Szerzō:

DR. HABIL. FRITZ PÉTER Egyetemi docens Ferencvárosi Torna Club, Miskolci Egyetem prritz@hotmail.hu Tudományos tevékenysége: doktori iskolában témavezetô Főbb kutatási terület: sporttáplálkozás, rekreáció

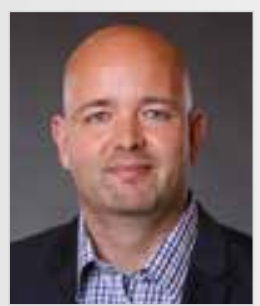

Szerző: DR. SZÁNTÓ ÁKOS

Egyetemi docens,

Eszterházy Károly Egyetem

\title{
A Modern Healthy Lifestyle koncepció The Modern Healthy Lifestyle concept
}

\section{- ÖSSZEFOGLALÁS:}

$A z$ internet megjelenése óta, de föleg a social media platformok megjelenése óta kifejezetten nagy hangsúly tevődik az egyén egészségét érintő döntéseire. A 2020-as év járványügyi helyzete rávilágított arra, hogy a modern kor technológiai vívmányai, valamint az információk sokasága még összetettebbé alakította az egészséges életmódot és annak fenntartási módjait. Az egészségtudatosság talán legfontosabb ismérve a jelenkorban az, hogy a túl sok információból ki tudjuk szűrni a valóban hitelt érdemlőket, és képesek legyünk az elméleti tudást a gyakorlatba, a napi rutinunk közé illeszteni. A jelen tanulmány bemutatja a modern healthy lifestyle koncepciót és annak társadalmi marketing vonatkozásait.

Kulcsszavak: egészséges életmód, holisztikus egészség, prevenció, társadalmi marketing, rekreáció, reziliencia, immunerősítés

ABSTRACT:

Since the appearance of the internet, but especially since the appearance of social media platforms, everyone has placed great emphasis on their decisions that affect the individual health. The epidemiological situation in $\mathbf{2 0 2 0}$ has highlighted that the technological advances of the modern age, as well as the wealth of information, have made the healthy lifestyle and its maintainance even more complex. Perhaps the most important criterion of health awareness today is that we can filter out effective creditors from too much information and be able to put theoretical knowledge into practice, into our daily routine. The study presents aspects of the modern healthy lifestyle concept and its social marketing.

\section{Bevezetés}

Az életmóddal összefüggő betegségek, az ún. civilizációs betegség, az elmúlt 5-10 évet tekintve Európában az első számú halálozási okokat jelentik. Ezek közé tartozik az érelmeszesedés, a szív-érrendszeri megbetegedések, stroke, elhízás, 2-es típusú cukorbetegség, a dohányzás, alkohol és drog okozta betegségek. Ezen betegségek megelőzhetők az immunrendszer és a rezilienciaképesség erősítésével, azaz egy modern egészséges életmóddal. Nem véletlen tehát az sem, hogy az egészséges életmód és az egészségturizmus rendkívül trendi, mert számtalan pozitív élettani hatása van annak, ha valaki fenn tudja tartani a testi-lelki egyensúlyát. A jelenlegi COVID-19 pandémia azonban mindent megváltoztat. Az eddigieken túl, azaz hogy saját magunkért a legmagasabb szintű felelősséget vállaljuk, a környezetünkért (természeti és a többi ember) is felelősséget vállalunk, valamint helyben, illetve belföldön töltekezünk, rekreálódunk testi és szellemi szinten.

„A turizmus egy olyan paradigmaváltáson fog keresztülmenni, amely több területet is érint majd, beleértve a döntéshozatalt, a desztináció és az közlekedési eszközök megválasztását, a digitalizációt és az innovációt, a biztonságot, a fenntarthatóságot és a helyi, fogadó közösség számára nyújtott előnyöket is" (Janech Péter, 202O, UNWTO).

A kormányoknak és a desztinációknak új egészségügyi protokollokat kell megalkotniuk és betartaniuk, és minden eddiginél jobban kell támaszkodniuk az adatok hatékony elemzésére a fogyasztók, vagyis az utazók védelmének érdekében, mindezt úgy, hogy közben innovatív és okos megoldásokat kínáljanak az ágazat szereplőinek. Újragondolás és újrapozicionálás szükséges mind az egészség, mind az egészségturizmus piacán.

\section{Milyen trendek mutatkoznak?}

- A személyre szóló szolgáltatások még inkább felértékelődnek.

- Az étkezés és mozgás immunrendszer-erősítő szerepe egyértelmű.

- A komplexitásból származó holisztikus módszerek nagyobb hatékonysága elvárás.

- A mentális egészség fontossága elengedhetetlen.

- Digitális detox.

- Hétköznapi rituáléink.

- Stresszmenedzsment.

\section{A Modern Healthy Lifestyle koncepció}

Innovatív modellekre, projektekre és megoldásokra van szükség, amelyek elősegítik az egészséges életmódot és az aktív időskort, mivel ezek fontos ösztönzői lehetnek az egészségügy fenntartható gazdaságának, különösen azokban az európai régiókban, amelyeket a lakosság elöregedése sújt - tartja az Európai Unió több szervezete (Front. Med., 2019).

A modern egészséges életstílus az egyéni felelősségvállalásra és tudatosságra épít, amely magával vonja a közösségi felelősségvállalást is. 
A koncepció középpontjában az az alapvetés áll tehát, hogy az egészség nem egy statikus, elérendő valami, hanem egy dinamikusan változó, a környezeti hatásokra reagáló pillanatnyi állapot.

Ez az állapot, azaz maga az egészség akkor tekinthető jónak, ha az az egyensúlyi állapotában van testi-lelki-szellemi aspektusból is. A környezeti hatásoktól, valamint az egyén rezilienciájának és immunrendszerének állapotától függ az egyensúlyi állapottól való eltérés mértéke, amely idővel különböző elváltozások formájában megmutatkozik az egyénen. Az egészségnek a visszaállítása a prevenció, a kuráció és a rehabilitáció skáláján jelenik meg, amelyek más-más eszközöket, szolgáltatásokat kívánnak meg.

„Primer prevenció alatt mindazon tevékenységek összességét értjük, melyek célja az egészség általános védelme, az egészségkárosodás és megbetegedés bekövetkezésének megelőzése" (Ádány, 2011. 9. o.).

A reziliencia általános értelemben rugalmas ellenállási képesség, azaz valamely rendszernek azon reaktív képessége, hogy erőteljes, meg-megújuló, vagy akár sokkszerü külső hatásokhoz sikeresen adaptálódjék; az ember gyorsan vissza tudja nyerni eredeti, jó állapotát testi-lelki szenvedés, illetve nehéz élethelyzetek átélése után.

A modern kor embere soha nem látott mértékü információhoz, tudáshoz, szolgáltatáshoz, technológiához tud hozzájutni az egészsége és életminősége kapcsán. A koncepciónk lényege, hogy primer prevenciós szinten mutassunk egy olyan életstílust, amely az immunrendszer erősítését és a rezilienciaképesség növelését tanítja a modern kor hétköznapjaiba integrálva.

A modern egészséges életstílus orvosszakmai keretét az életmódorvoslás és rekreáció kombinációja adja, amelyet a Magyar Életmód Orvostani Társaság alapító elnöke, dr. Babai László, valamint a Közép-Kelet-Európai Rekreációs Társaság alapító elnöke, dr. Fritz Péter állított össze.

Az életmódorvostan a bizonyítékokon alapuló orvostudomány egyik ága, mely - az életmóddal összefüggő betegségek alap kiváltó okait megcélozva - átfogó életmódváltást (köztük táplálkozás, fizikai aktivitás, stresszmenedzsment, szociális támogatás és környezeti hatások befolyásolása) használ az életmóddal összefüggő betegségek megelőzésében, gyógyításában, progresszió lassításában.

Az életmódorvoslás interdiszciplináris ág, mely átöleli az orvostudományt, a pszichológiát, a népegészségtant és a biológiát. Legfontosabb céljának ugyanúgy tartja az életmód szokások befolyásolása révén az elsődleges prevenciót, mint az életmóddal összefüggő betegségek közös kóroki és kórélettani eltéréseinek kezelését.

„A rekreáció szabadidőben, a tevékeny pihenés érdekében végzett minden olyan kulturális, társas, játékos és mozgásos tevékenység, melyet a napi fő elfoglaltság által okozott fáradtság, feszültség feloldása, a testi-lelki teljesítőkészség és képesség helyreállítása, fokozása érdekében tesz az ember" (Fritz, 2011, 28. o.).

\section{A Modern Healthy Lifestyle mint termék}

Az egyéni felelősségvállalásra, a fenntartható egészséges életmódra építünk, azaz az egyensúly megtalálására, fenntartására.

- Ennek kulcsa az, hogy megtanítjuk arra az embereket, hogyan tudják a modern 21. században magukat kibalanszírozni a különböző rekreációs tevékenységekkel, illetve hogyan tudják fenntartani a test-lelki egyensúlyukat, meghosszabbítva az egészségben eltöltött éveik számát.

- Megmutatjuk számukra, melyek a tudomány legújabb vívmányai ahhoz, hogy otthonukban és a hétköznapjaikban is a saját és a környezetük testi-lelki egészségére maximálisan tudjanak figyelni.

A modern egészséges életstílus megismertetése életmód-változtatást elősegítő csomagok értékesítésével történik egy olyan intézményben, amely egyben szállodaként is funkcionál. Ennek egyrészt az az oka, hogy az életmódváltáshoz időre van szükség, 1-2-3-4 hetes intervallumokra; másrészt pedig a modern healthy lifestyle bárki számára hozzáférhető a világ bármely pontjáról. Az életmód szálloda így rendelkezik egy fitnesz- és mozgásteremmel, egy látvány- és tankonyhával, egy fürdővel, szépészeti és masszázshelyiségekkel, és az orvosi felmérésekhez és tanácsadáshoz szükséges helyiségekkel, berendezésekkel és felszerelésekkel is. A szálloda azonban nem csak szállóvendégeknek nyújt szolgáltatásokat, hanem helyi lakosok, illetve más szállóban megszálló turisták részére is.

\section{A Modern Healthy Lifestyle termék 4 pillére}

\section{Pillér: Lifestyle medicine}

\section{Életmódorvoslás a speciális szolgáltatásunk}

Az életmód-változtatást elősegítő csomagok mindegyikének a gerincét az életmódorvoslás 5 lépcsős folyamata adja. Ezek lépései a következőek:

\section{Életmód orvosi felmérés}

Az életmód orvosi felméréssel tájékozódunk a szervezet pillanatnyi állapotáról. A felmérés az életmóddal összefüggő betegségek gyógyításához / megelőzéséhez szolgáló életmódprogram kiindulópontja. Így a felmérés ezen betegségek rizikótényezőinek detektálására koncentrál.

Orvosi felmérés: átfogó szemléletű orvosi felmérés, ahol a fó hangsúlyok az anyagcserét, szív-érrendszert, mozgásszervrendszert érintő rizikótényezők (családi, genetika, életmód) beazonosításán, a kezdődő vagy meglévő elváltozások detektálásán, korábbi orvosi vizsgálatok eredményeinek, szedett gyógyszereknek, kapott kezelésnek az áttekintésén vannak.

Edzői, gyógytornászi felmérés: vázizomrendszer, erőnlét, szív-érrendszer, fittség felmérése.

Dietetikai felmérés: táplálkozási szokások feltérképezése, testösszetétel-vizsgálat, vérképelemzés.

Mentálhigiénés felmérés: személyes élethelyzet, pszichoszociális környezet, motivációk feltérképezése.

Az állapotfelmérés eredményeiból elkészül a személyes „betegség-kockázati térkép”. A térkép tartalmazza az életmóddal összefüggő betegségek kialakulásának személyes kockázatait. Alapját képezi a személyre szabott gyógyító, megelőző, egészségfejlesztő életmód összeállításának.

\section{Személyre szabott életmód összeállítása}

A betegségek gyógyítása, megelőzése érdekében az életmódorvoslás célja a feltárt kockázatok csökkentése, az egyéni betegségkockázati térképnek megfelelő étkezés, mozgás, stresszmenedzsment kialakítása és követése.

\section{Életmódprogram kivitelezése \\ szakmai segítséggel}

Az életmódváltás legtöbbször több éve-évtizede rögzült szokások megváltoztatását, módosítását teszi szükségessé. Szakembereink kezdetektől segítenek a lépésről lépésre tör- 
ténő váltásban, a biztonságos mozgásban, egészséges étkezésben, mentális vezetésben.

\section{Rendszeres ellenőrzések}

Az egészségfejlesztés egy életre szól. Az élet előrehaladásával a hatékonyság fenntartása érdekében az állapot rendszeresen felülvizsgálatra, az alkalmazott eljárások pedig igazításokra szorulnak

\section{Egyéni egészségterv}

Az egyéni egészségterv egy személyre szabott cselekvési program, amely minimálisan tartalmazza az egyén egészségi állapotának megfelelően a betegségek megelőzését, a kialakult betegségek gyógyítását szolgáló orvosi, étkezési, mozgási és pszichés teendőket.

Az egyéni egészségterv egészséggé alakulása az egyén, a kliens területe, egy életen át tartó folyamat. A szakmai segítők jelenléte, a rendszeres kontrollvizsgálatok elvégzése szükséges a megfelelő hatékonyságú, mellékhatásoktól mentes teendők meghatározásához, az egészségben bekövetkező változások detektálásához, az életmódeszközök szükség szerinti folyamatos igazításához.

Látvány- és tankonyha a Tokaj-hegyaljai borvidékre is építve

A látványkonyhában tudják majd a vendégek elsajátítani a javasolt új életmódnak megfelelő ételek elkészítését. Az oktatás csoportos lesz, ezért szükséges, hogy minden résztvevő saját munkapulttal, mosogatóval, főzőlappal és sütővel rendelkezzen. A táplálkozási tanácsadást a Superfoods Kft. által tartjuk a leghatékonyabbnak, mert többéves sikeres szakmai és oktatói múlttal rendelkeznek a témában.

\section{Fitnesz- és mozgásterem}

A szolgáltatások között lesznek csoportos órák, gyógytornák, személyi edző segítségével végzett programok, illetve önállóan is használhatják majd a termet mind a szállóvendégek, mind a szállodán kívülről érkező vendégek.

\section{Mentálhigiénia}

A holistic stressmanagement a fő irányvonal.

\section{Pillér: Edukáció, azaz a fejlesztés biztosítása}

Az edukáció egyrészt egy elméleti programban való részvétel, valamint életmódtáborokban történő gyakorlati tudás elsajátítása.

\section{Modern Healthy Lifestyle edukációs program}

1. MEGÉRTÉS, melynek célja: tudatosságnövelés, információátadás a holisztikus szemléletről

2. MEGÉLÉS, melynek célja: az egyéni érzések, minták gondolati sémák feltérképezése és átélése

3. MỨKÖDTETÉS, melynek célja: további személyes problémák, feladatok megoldása

Modern Healthy Lifestyle táborok

\section{Pillér: Az egészségturizmus bevételének $50 \%$-a fürdőszolgáltatásból származik.}

\section{Egyedülálló víz biztosítása elengedhetetlen - Kaqun és Doterra wellness}

A KAQUN ${ }^{\mathrm{TM}}$ egy magyar találmány, amellyel sikerül oxigént bevinni a szövetbe biztonságosan, és így be tudjuk indítani a mitokondriumok múködését, és visszafordítani a negatív folyamatokat.

A Doterra illóolajok bevonása indokolt a wellnessrészlegnél!
A tiszta illóolajok felhasználhatók fizikai, szellemi és érzelmi segítségre a mindennapi életben.

\section{Pillér: Healthy aging, természetes anyagok, egyensúly - fókuszban önmagunk!}

\section{Szépészeti stúdió - Jeunesse és megjelenés}

A szépészeti stúdió a Jeunesse termékekre épít, amely a legdinamikusabban növekvő márka a területen. A növekedés mögött a világ élvonalbeli technológiái állnak, többek között a humán őssejtek.

\section{A Modern Healthy Lifestyle lokációja}

A Modern Healthy Lifestyle első tervezett helyszíne Miskolc. A városban gyógyklimatikus hely is van, ahol tradicionálisan a levegő minőségével is gyógyítottak. A Csanyik-völgy Miskolc egyik kedvelt kirándulóhelye Diósgyőr és Lillafüred között, a város egyik legnagyobb egybefüggő zöldterülete. Itt található a helyi állatkert, a Vadaspark is. A rendszerváltás előtt a terület egy részén KISZ-tábor múködött, amiben később tüdőszanatórium üzemelt. Az épületkomplexum évek óta üresen áll.

A hely tervezett hasznosítása a városfejlesztési stratégiába is bekerült az alábbiak szerint: „Olyan egészségügyi központ létrehozása vagy korszerü idősotthon, ápolási központ, amely az ellátottak számára minden egészségügyi szolgáltatást egy helyen tud biztosítani a diagnózis felállításától, a beavatkozáson keresztül a teljes felépülésig. Diagnosztika, terápia, fizikoterápia, sportrehabilitáció, prevenció, esztétika egy helyen!"

Ahhoz, hogy a tervekből valóság legyen, elengedhetetlen, hogy az érintettek csatlakozzanak a koncepcióhoz. Azt valljuk, hogy a társadalmi jóllét növelése akkor a leghatékonyabb, ha feladatorientált szemléletból indulunk ki, és így az állam, a vállalkozások, a civil szektor és az egyének egyaránt tudatosan részt vesznek a folyamatban. Így, hogy mindenki teljesíti a feladatát, azaz a közös cél érdekében mindenki az erősségeit használva hozzátesz valamit a projekthez, hatékonyabb megoldások születhetnek.

Az általunk értelmezett, a témához kapcsolódó érintettek köre is ezt a szemléletet mutatja, és a következőkben megfogalmazott marketingstratégia a társadalmi és a holisztikus marketing sajátosságaira épít.

Miskolci lokáció esetén az érintettek: Magyar Turisztikai Ügynökség, Miskolc Megyei Jogú Város, Beutaztatásban részt vevők, Miskolci Egyetem, Magyar Életmód Orvostani Társaság, Közép-Kelet-Európai Rekreációs Társaság, Életmódhoz kapcsolódó szervezetek, Élményt nyújtók, Lakosság.

\section{A Modern Healthy Lifestyle kommunikációja}

A kommunikációs csatornák 3 nagy csoportját alkalmazzuk: személyes kommunikáció (workshop, kiállítás, study tour, országspecialisták, események), online kommunikáció ( $k p-i$ landing page, social media) és offline kommunikáció (Recreation tudományos magazin, felkérö levelek, rádió és tv).

A potenciális kereslet online csatornán, a többi stakeholder pedig személyes csatornán és offline módon kerül elérésre.

\section{Személyes kommunikáció}

A személyes kommunikációban, a kapcsolatmenedzsmentben látjuk a prevenciós és rehabilitációs piac felépítésének leghatékonyabb módját. Ilyen módon tudjuk a szak- 


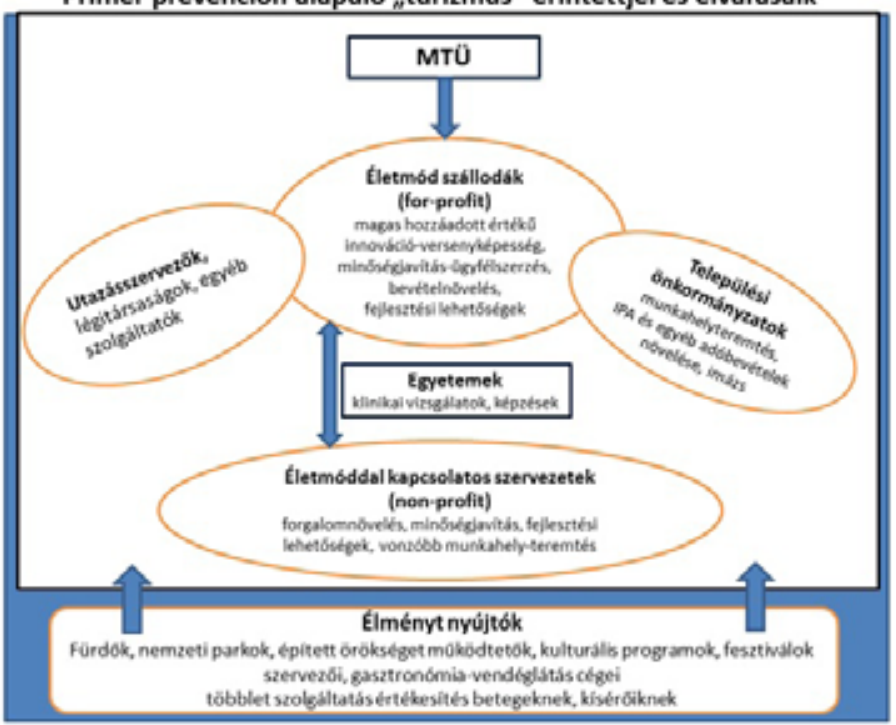

1. ábra Forrás: Saját szerkesztés

mai és módszertani információkat eljuttatni a legkevesebb információvesztéssel. A kommunikáció tartalma két markáns témakört ölel fel. Az egyik a turisztikai szegmens, a másik az egészségügyi szegmens. A két témakör más-más tartalmi és stílusbeli kommunikációt és érdekeltséget tartalmaz, ezáltal indokolt a tagoltsága.

\section{A ,recreation" tudományos magazin, rovat: Mo- dern Healthy Lifestyle}

A Közép-Kelet-Európai Rekreációs Társaság (KERT) 2010-ben rekreacio.eu néven tudományos magazint alapított. A magazin jelenleg recreation címen jelenik meg, amely hiteles, független szakmai lapként, a nemzetközi tudományos publikációs elvárásoknak megfelelően, környezettudatos és esztétikus megjelenésével, a rekreáció és annak határterületein folyó kutatási eredményekről, trendekről, alkalmazott eljárásokról, szolgáltatásokról, gasztronómiáról, sporttáplálkozásról, turisztikai attrakciókról számol be magyar és angol nyelven. A magazin a rekreáció, az egészségfejlesztés és -megőrzés, valamint a turizmus területén ma egyedülálló Magyarországon, negyedévente jelenik meg, 4000 példányszámban, értékesítése a LAPKER Zrt. kiskereskedelmi hálózatán keresztül történik, valamint online formában is. A tudományos magazint a Magyar Tudományos Múvek Tára (MTMT) 2012-ben hivatalosan is regisztrálta és tudományos minősítésűnek ismerte el, melynek ISSN száma: 2062-6436. A tudományos cikkek ref DOI-szintű nemzetközileg elismert besorolást kapnak, igazodva ezzel a nemzetközi szakmai publikációs elvárásokhoz.

\section{A program megismertetése a laikus közvéle- ménnyel}

- Központi landing page - Saját honlap: www.modernhealthylifestyle.hu

- Témaspecifikus honlap és/vagy portál webshoppal (érintettek)

- Tájékoztató és felkérő levelek településvezetőknek, oktatási intézményvezetőknek, munkáltatóknak, egyházi vezetőknek, kapcsolódó civil szervezeteknek

- Események, rendezvények, életviteli klub a téma „kézzelfoghatósága" érdekében

- Online, social media felületek létrehozása, múködtetése, tartalmak gyártása

- Online elérhető szakmai hivatkozások, cikkek, tanulmányok, konferenciamegjelenések

- Interjúk, rádiós, tv-s háttérbeszélgetések vitamüsorokban, tömegmédiában és social médiában

\section{A program megismertetése a szakmai közvéle-} ménnyel

- Szakmai érintettek

- Szakmai döntéshozók

- Végrehajtó szervek

- Orvosszakmai kongresszusok, konferenciák, szimpóziumok keretében edukáció a szűrővizsgálatokról (kérdőivek)

- Interjúk, rádiós, tv-s háttérbeszélgetések vitamúsorokban, közmédiában, ami integrált kommunikációs stratégia mentén online és print felületeken is megjelenik

- PR és tájékoztató anyagok

\section{Konklúzió}

A modern kor történetében, de talán soha még ezelőtt, nem volt olyan mértékü felelősségvállalási kényszer az emberekben, mint manapság. Talán soha nem volt nagyobb szükség arra, hogy a legjobb tudásunk szerint, a leghatékonyabban tudjuk óvni az egészségünket, vagy a leggyorsabban tudjuk azt helyreállítani. Azt az erőforrást, önmagunkat, amely egy boldog élet alapja. És talán soha ilyen mértékü környezettel való együttmúködésre sem volt példa, amely jól mutatja az egészség értelmezésének bővülését is. Azaz nemcsak az egyén egészsége függ az őt körülvevő környezettől, hanem a környezet egészsége is függ az egyéntől. A kölcsönös kapcsolat és egymásra gyakorolt hatás vitathatatlan. Új ismeretekre, új készségekre, új életstílusra van szükség. Ennek elsajátítása sürgető, már-már égető. Nagyon sokat lehetett hallani arról, mit kell tennie az egyénnek. A mostani pandémia rávilágított arra, hogy minden társadalmi szereplő hatással van egymásra, felelős a másikért. Hogyan tudunk a leghatékonyabban tenni annak érdekében, hogy az egyének, a családok, a közösségek egészségesebbek legyenek? Minden társadalmi szereplő felelősségét és beavatkozási pontjait megvizsgálva arra jutottunk, hogy a társadalmi marketing stakeholder menedzsment szemléletére építve egy olyan koncepciót állítunk össze, amely új köntösbe helyezi az egészséges életmód „eladását”. A koncepció kialakításában és kivitelezésében azok a szakmai szervezetek és azok a szakemberek vesznek részt, amelyek hosszú évek óta elkötelezettek és gyakorlói a témának. A tanulmányban bemutatunk egy lehetséges helyszínt, amely elsőként lehet a Modern Healthy Lifestyle koncepció gazdája. Azonban a koncepció alkalmas arra, hogy egyének, családok, közösségek is igénybe vegyék. Ezáltal a jövőben a koncepció további finomítása és „értékesítése” is várható.

\section{Irodalomjegyzék}

1. Dózsa Csaba - Mató-Juhász Annamária (2020): Az egészséges életmód turisztikai termékké való alakítása, Sárospataki turizmusfejlesztési tanulmányok 2020., Sárospatak és Környéke Turizmusáért Egyesület 2. https://turizmus.com/utazas-kozlekedes/unwto-a-biza-

lom-es-az-egyuttmukodes-donto-a-turizmus-ujraindulasahoz-1170517

3. Ádány Róza (2011): Megelőző orvostan és népegészségtan, Medicina Könyvkiadó Zrt.

4. Dr. Fritz Péter (2011): Mozgásos rekreáció: rekreáció mindenkinek I. Bába Kiadó, Szeged

5. Miskolc Megyei Jogú Város - Városfejlesztési stratégia

6. Development of a Healthy Lifestyle Assessment Toolkit for the General Public, Frontiers in Medicine, 27 June 2019| https://doi.org/10.3389/ fmed.2019.00134

7. https://emot.hu

8. https://recreationcentral.eu/

9. http://kaqunviz.com/

10. https://www.doterra.com/US/en 